\title{
Ūminis vaikų kvèpavimo nepakankamumas
}

\author{
Jurgita Pečiulytė, Vaidotas Gurskis \\ LSMU MA Vaikų ligų klinika
}

Reikšminiai žodžiai: kvėpavimo nepakankamumas, kvejpavimo nepakankamumo patofiziologija, vaikų kvėpavimo sistemos anatomija, vaikų kvėpavimo nepakankamumo gydymo taktika.

Santrauka. Ūminis kvèpavimo nepakankamumas yra dažniausia priežastis, dèl kurios vaikai patenka ì gydymo įstaigą. Svarbu suprasti fiziologinius, anatominius ypatumus, patofiziologinius mechanizmus, kurie paaiškina dažnesnį vaikų mirštamumą nuo kvėpavimo nepakankamumo. Svarbu laiku atkreipti dèmesị i klinikinius simptomus, teisingai interpretuoti fizinę apžiūrą diagnozuojant ūmini kvèpavimo nepakankamumą. Tinkamas fizinis ištyrimas ir bendrosios būklès vertinimas padeda tiksliai nustatyti priežastį, sukẻlusią üminį kvėpavimo nepakankamumą ir padaryti reikiamus sprendimus pradedant gydymą.

Kvépavimo nepakankamumas (KN) yra gyvybei pavojingas kvèpavimo funkcijos sutrikimas, kurio pradžia gali būti staigi arba ilgai besitęsianti, trukti nuo keliụ valandų iki keliu dienuc, greitai progresuojantis ir besitęsiantis nuo kelių dienų iki savaičių [1]. Svarbiausia kvejpavimo funkcija užtikrinti dujų apykaitą, t. y. oksigenaciją (issotinimą deguonimi) ir anglies dvideginio $\left(\mathrm{CO}_{2}\right)$ pašalinimą.

Literatūros duomenimis, dèl kvèpavimo sutrikimo i vaiku priemimo skyriu atvyksta $10-20$ proc. pacientu [2], o penktadaliui ligoninèse gydomu vaikų diagnozuojamas kvépavimo nepakankamumas.

Šis skaičius vaiku intensyviosios terapijos skyriuose dar grèsmingesnis: čia dèl kvèpavimo nepakankamumo patenka kas antras ligonis [3]. Ūminès kvejpavimo taku infekcijos lemia apie 20 proc. visu vaiku iki 5 metu mirčiu [5]. Negebejjimas atpažinti ligos simptomų yra vienas dažniausių didesnio vaiku mirštamumo veiksnių. Ši klaida dažniausiai padaroma per pirmąji sergančio vaiko kontaktą su sveikatos priežiūros îstaigos darbuotojais. Neteisingas kvépavimo nepakankamumo klinikos įvertinimas, negebejjimas ištirti vaiką ir interpretuoti fizinius požymius lemia blogas baigtis. Ankstyvas simptomu atpažinimas, laiku suteiktas gydymas gali nutraukti patofiziologinius procesus, dèl kurių išsivysto kardiopulmoninis nepakankamumas [6].

\section{APIBRĖŽTIS}

Kvépavimo nepakankamumas - tai sindromas, kai kvejpavimo sistema negeba užtikrinti dujų apykaitos: oksigenacijos (issotinimo deguonimi) ir $\mathrm{CO}_{2}$ pasišalinimo, atitinkančius organizmo metabolinius poreikius.
Kvėpavimo funkcija realizuojama per kelias grandis:

1. $\mathrm{O}_{2}$ apykaita tarp aplinkos ir plaučiu alveolių;

2. $\mathrm{O}_{2}$ difuzija per alveolinę-kapiliarinę membraną;

3. $\mathrm{O}_{2}$ difuzija iš plaučiu $\mathfrak{i}$ organus (priklauso nuo širdies išstūmio tūrio ir hemoglobino koncentracijos);

4. $\mathrm{CO}_{2}$ pašalinimas iš kraujotakos.

KN gali būti apibrèžtas pagal kraujo dujų nuokrypi, kai $\mathrm{PaO}_{2}$ (parcialinis deguonies slègis) yra mažesnis nei $60 \mathrm{mmHg}$ kvejpuojant oru ar $\mathrm{PaCO}_{2}$

1 lentelè. Dažniausios vaikų kvèpavimo nepakankamumo priežastys

Kvėpavimo takų ligos

- Viršutinių kvėpavimo takų obstrukcija (pvz.: krupas, svetimkūnis, epiglotitas, tonzilių hipertrofija)

- Apatinių kvėpavimo takų obstrukcija (pvz.: bronchiolitas, astminè būklè, bronchopulmoniné displazija)

- Plaučių ligos (pvz.: pneumonija, ūminis kvėpavimo sutrikimo sindromas, plaučių edema)

\section{Ventiliacijos sutrikimas}

- Nervų ir raumenų ligos, miopatijos, Guillain-Barre sindromas

- Krūtinès ląstos traumos ir igimtos deformacijos, sunki igimta skoliozė

- Skystis pleuros ertmeje, pneumotoraksas

Nepakankama ventiliacija dèl centrinès nervų sistemos patologijos

- Status epilepticus, infekcija centrinès nervų sistemos, intoksikacija, traumos, neišnešiotų kūdikių apnèja

Padidèjęs deguonies poreikis

- Hipovolemija, sepsinis šokas

- Širdies nepakankamumas

- Medžiagur apykaitos sutrikimai, apsinuodijimas 
(parcialinis anglies dvideginio slègis) didesnis nei $55 \mathrm{mmHg}$, arterinio kraujo $\mathrm{O}_{2}$ saturacija $\left(\mathrm{SaO}_{2}\right)<92(90)$ proc.

Kvėpavimo nepakankamumas gali vystytis dèl igimtų plaučių ligų, kvèpavimo takų ligu ar nepakankamų kvépavimo pastangų. Esant sunkiai būklei, gali būti sunku iš karto aiškiai atskirti kvépavimo nepakankamumą nuo kraujotakos nepakankamumo, nes abi sistemos užtikrina oksigenaciją, o klinikiniai hipoksemijos požymiai, nesvarbu, kokia pradinė ją sukèlusi priežastis, nesiskiria (1 pav.).

Dažniausios vaikų kvėpavimo nepakankamumo priežastys nurodytos 1 lentelèje.

\section{KODE்L VAIKAI SERGA SUNKIAU}

Kūdikių ir suaugusiųjų kvèpavimo fiziologijos skirtumų žinojimas padeda suprasti, kodèl kūdikiai ir maži vaikai jautresni, greičiau ir sunkiau serga kvėpavimo ligomis, kodèl kvépavimo nepakankamumas yra dažna problema naujagimiu ir vaiku intensyviosios terapijos skyriuose (2 lentelè).

Metabolizmas. Pagrindinẻ kūdikių medžiagu apykaita normaliomis sąlygomis yra apie 2-3 kartus didesnè nei suaugusiųjų. Tai reiškia, kad kūdikiai turi mažesni deguonies rezervą, ypač jei jo suvartojimas padideja sergant.

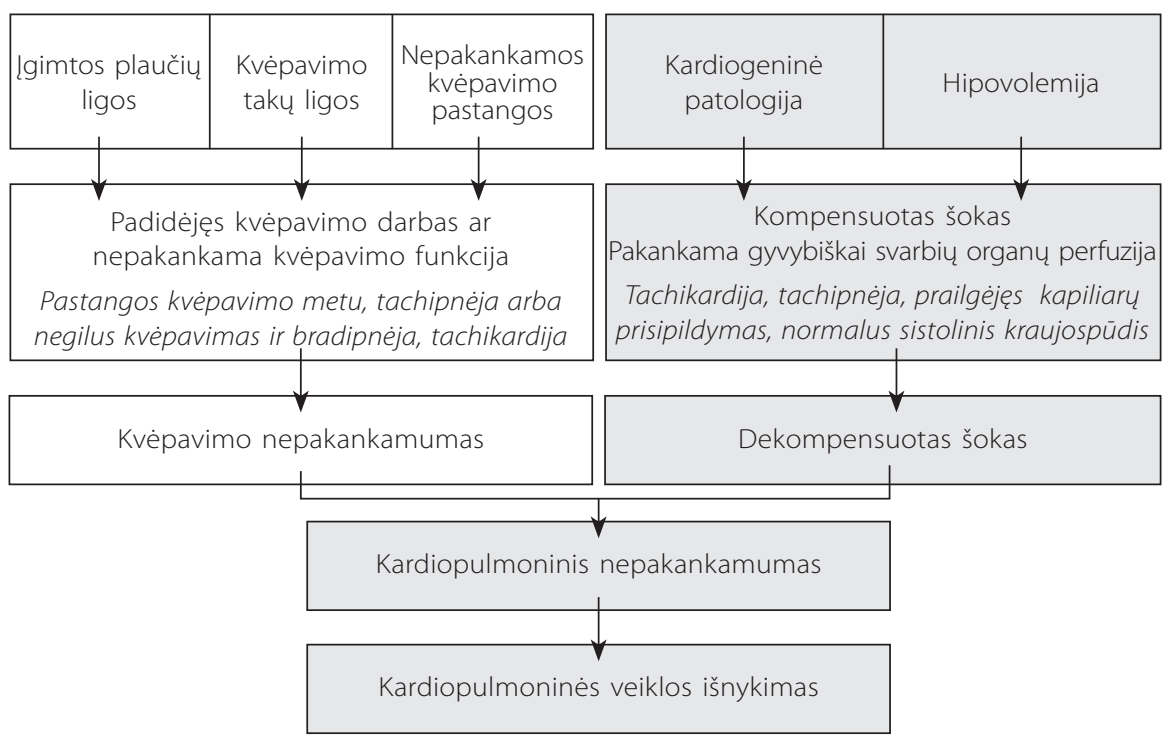

1 pav. Kardiopulmoninio nepakankamumo vystymosi schema
Kvėpavimo kontrolè. Kvėpavimo reguliaciją atlieka centrai, esantys pailgosiose smegenyse, jie galutinai susiformuoja per paskutiniąsias nèštumo savaites ir pirmąsias dienas po gimimo. Tai paaiškina didelị apnejos paplitimą kūdikių, gimusių anksčiau laiko, grupėje. Kvėpavimas yra nereguliarus, o tam tikrų būkliu atveju dideja hiperkapnijos ar hipoksijos rizika [7].

Apatiniai ir viršutiniai kvẻpavimo takai. Vaiko kvejpavimo takams susiaurejjus $1 \mathrm{~mm}$, skerspjūvis sumažèja 75 proc., pasipriešinimas oro srovei padideja 16 kartų, tuo tarpu suaugu-
2 lentelè. Vaiku kvèpavimo fiziologijos ypatumai

\begin{tabular}{|c|c|}
\hline Priežastys & Fiziologija ir anatomija \\
\hline Greitesnis metabolizmas & Dideja $\mathrm{O}_{2}$ suvartojimas \\
\hline Didesnè apnèjos rizika & Nesubrendęs kvėpavimo centras \\
\hline $\begin{array}{l}\text { Didesnis viršutinių kvėpavimo takų } \\
\text { pasipriešinimas }\end{array}$ & $\begin{array}{l}\text { Kvėpuoja pro nosị } \\
\text { Didelis liežuvis } \\
\text { Siauresni kvėpavimo takai } \\
\text { Greičiau subliūkšta } \\
\text { Mažesnis ryklès raumenų tonusas }\end{array}$ \\
\hline $\begin{array}{l}\text { Didesnis apatinių kvėpavimo takų } \\
\text { pasipriešinimas }\end{array}$ & $\begin{array}{l}\text { Kvėpavimo takai siauresni } \\
\text { Kvėpavimo takai greičiau subliūkšta } \\
\text { Smarkesnis kvejpavimo takų sienelių subliūškimas } \\
\text { Mažiau elastinio audinio }\end{array}$ \\
\hline Mažas plaučių tūris & $\begin{array}{l}\text { Mažiau alveolių } \\
\text { Nesusiformavusi kolateralinè ventiliacija }\end{array}$ \\
\hline Tarpšonkauliniai raumenys nebrandūs & $\begin{array}{l}\text { Šonkaulių padėtis horizontali } \\
\text { Diafragma plokštesnè } \\
\text { Diafragmos raumenys nebrandūs } \\
\text { Tarpšonkauliniai raumenys nebrandūs }\end{array}$ \\
\hline $\begin{array}{l}\text { Nepakankama kvėpavimo raumenų } \\
\text { ištvermé }\end{array}$ & $\begin{array}{l}\text { Didesnis kvėpavimo dažnis } \\
\text { Mažesnis I tipo raumeninių skaidulų skaičius }\end{array}$ \\
\hline
\end{tabular}

siųju kvėpavimo takų praeinamumas sumažeja 44 proc., pasipriešinimas padidèja tik 3 kartus ramiai kvėpuojant. Esant apatinių kvépavimo taku obstrukcijai, dideja forsuoto iškvèpimo pastangos, tuo pačiu dideja vidinis krūtinès ląstos slègis. Todèl iškvèpimo stridoras lemia tolesnị iškvepiamo oro srauto mažejjimą (pvz., didejjanti viršutinių ir apatinių kvèpavimo takų obstrukcija, verkimo metu). Suprasti ši dinamišką kvėpavimo takų subliūškimo reiškini yra itin svarbu gydant vaikus. Labai svarbu apsaugoti vaiką nuo streso, pašalinti dirgiklius, galinčius sukelti baimę (2 pav.).

Susidarius turbulencinèms srovėms, pvz., vaikui verkiant, kvėpavimo darbas padideja 32 kartus. Vaikuc gerklos yra aukščiau nei suaugusiųju (atitinkamai ties kakliniu C3 ir C6 slanksteliais), siauriausia vieta - ties

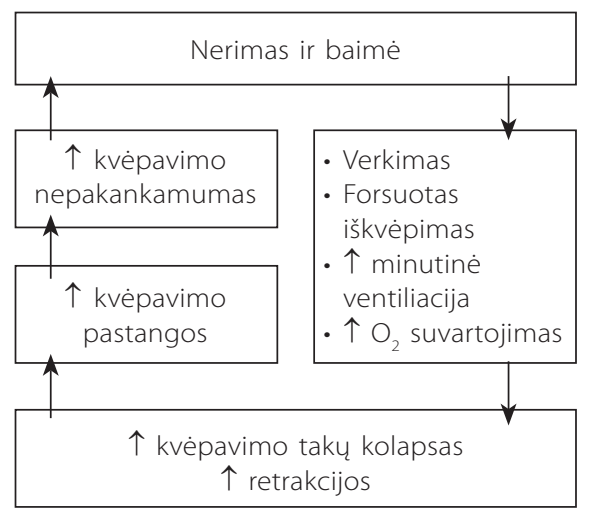

2 pav. Nerimo ir baimès sukeltas kvèpavimo taku obstrukcijos ciklas vaikams 
žiedine kremzle, jos yra elastingesnès. Vaikų alveolių elastinès skaidulos nèra gerai išsivysčiusios, todèl gali lengviau subliūkšti [8].

Krūtinès ląsta ir kvẻpavimo raumenys. Mažų vaikų krūtinès ląstos siena yra elastingesnè, tarpšonkauliniai raumenys nebrandūs, šonkaulių padètis horizontali, diafragma plokštesnè, paradoksinio kvėpavimo metu tarpšonkaulinių raumenų judesiai tampa nekoordinuoti. Kvėpuojamieji raumenys ne iki galo susiformavę ir subrendę. Krūtinès ląstos būklè „ekspiracinè (šonkauliai sudaro tiesu kampą su stuburu). Ribotos galimybès didinti kvèpavimo tūrị ir ịveikti pasipriešinimą obstrukcijos metu greitai susilpneja, nes pavargsta kvejpuojamieji raumenys. Be to, ir diafragmos padètis yra „aukšta“. Tarpusienis labai paslankus, todèl jam pasislinkus, suspaudžiamas plautis, perlinksta stambiosios kraujagyslès (3 pav.).

Plaučių parenchima. Vaikų acinusas „primityvus“, kolateralinè ventiliacija menka, todèl dideja atelektazių rizika. Tarpalveolinis ir tarpskiltinis jungiamasis audinys yra purus, plaučiuose gausu kraujagyslių. Blogesnè dujų difuzija ir sunkesnis $\mathrm{O}_{2}$ pasisavinimas, didesnis polinkis $\mathfrak{i}$ plaučių edemą ir infekcijos išplitimą yra būdingi vaikams. Tai pat tachipnejjos metu sumažèja kvėpuojamasis tūris. Pleura plona, švelni, o pleuros elastinis tinklas formuojasi iki $7 \mathrm{~m}$. amžiaus. Greta esantys audiniai yra purūs ir pažeidžiami, todèl, pleuros ertmèje kaupiantis skysčiui, lengvai nustumiami tarpusienio organai.

Vaikų kvėpavimo organų anatominiai ir fiziologiniai ypatumai turi didesnę reikšmę iki $8 \mathrm{~m}$. amžiaus; išorinio kvėpavimo funkcinis efektyvumas pasiekia suaugusiųjų tik sulaukus vyresniojo mokyklinio amžiaus.

\section{Klinikinio vertinimo nauda}

Dažniausiai nėra konkrečių simptomų, atitinkančių konkrečią kvépavimo takų ligą, bet teisingas klinikinių požymių interpretavimas leidžia nustatyti priežastis ir pažeidimą. Patofiziologija pagrịstas požiūris ir teisingas anamnezès interpretavimas bei klinikinių požymių supratimas naudingiausi vertinant kvėpavimo nepakankamumo

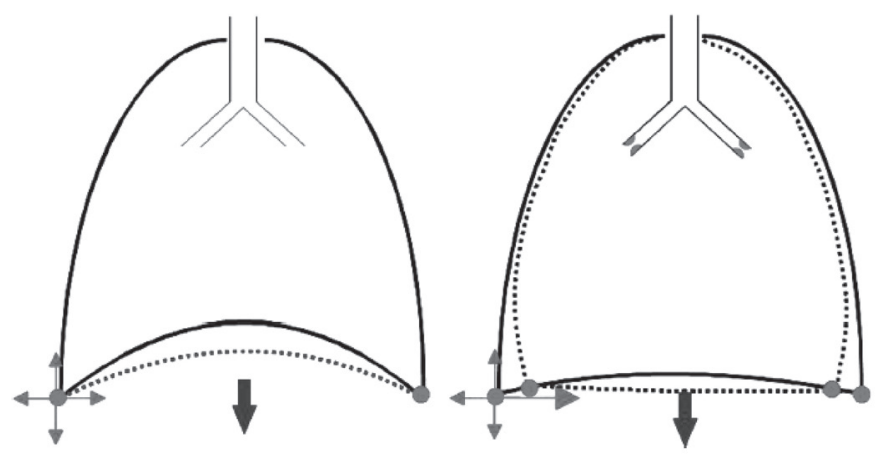

3 pav. Vaiku kvèpavimo fiziologija

Tarpšonkauliniai raumenys ir diafragma yra priešingi vidiniams tarpšonkauliniams raumenims (ekspiraciniams), kurie ramaus kvepavimo metu juda labai letai (kairioji schema). Paradoksinio kvèpavimo metu pradeda veikti pagalbiniai iškvépimo raumenys, diafragma suplokštejja, plaučiu tūris tampa mažesnis (dešinioji schema). sunkumą [10]. Pirmoji užduotis, vertinant vaiką, kuriam yra kvėpavimo nepakankamumas, numatyti pagalbos apimti, parinkti deguonies terapijos metodą (pvz., neinvaziniai deguonies terapijos metodai ar dirbtiné plaučiuc ventiliacija). Esant sunkiam kvejpavimo nepakankamumui, šis sprendimas turi būti priimtas pirmosiomis minutėmis. Todèl žinoti klinikinius simptomus yra itin svarbu (pagalbinių raumenų dalyvavimas kvėpuojant, kvėpavimo, sąmonès lygmuo).

Pirmiausia reikia îvertinti, ar vaikas kvejpuoja spontaniškai, ar kvépavimo takai atviri. Esant kvejpavimo takų nepraeinamumui, svarbiausia užtikrinti jų praeinamumą. Skubios intervencijos, kaip antai: siurbimas, apatinio žandikaulio pakèlimas ir, jei reikia, ventiliacija, dažnai gali būti atliekamos iš karto [11]. Sèkminga ventiliacija pro kaukę atliekama esant tinkamai galvos padéčiai, iškèlus apatinị žandikaulị, parinkus tinkamą veido kaukę. Esant visiškai svetimkūnio sukeltai kvėpavimo takų obstrukcijai, jis šalinimas Heimlicho metodu, jei vaikas sąmoningas. Negalint pašalinti svetimkūnio iš kvèpavimo takų ir vaikui paradus sąmonę, turi būti atliekamas pradinis vaiko gaivinimas. Kvėpavimo takų atvėrimo metodai (galvos atlošimas, apatinio žandikaulio pakẻlimas) yra paprasti ir efektyvūs, tačiau turètų būti atliekami atsargiai pacientams, kuriems yra adenoiduc ir tonzilių hipertrofija [12], nes dalinė obstrukcija gali virsti beveik visiška kvėpavimo taku obstrukcija. Tokiu atveju kvėpavimo taku praeinamumui palaikyti galima naudoti pagalbines priemones orofaringini ar nazofaringini vamzdelị.

Jei vaikas kvėpuoja spontaniškai, reikia įvertinti kvėpavimo dažní, kvèpavimo mechaniką, spontaninio kvèpavimo efektyvumą ir kvejpavimo nepakankamumo pasekmes kitų organų sistemoms. Tachipnėja dažniausiai yra pirmasis pasireiškiantis simptomas esant kvépavimo sutrikimui (distresui). Tachipnejja su stridoru ar švokštimu paprastai pasireiškia vaikams, turintiems kvėpavimo takų patologiją, ir dažniausiai yra padidejusio kvẻpavimo darbo priežastis. Priešingai, tachipnèja be papildomų pastangų dažniausiai ivyksta ne dèl plaučių ligų, ją gali sąlygoti sunki metabolinè acidozè, šokas, diabetinè ketoacidozè, paveldimos medžiagu apykaitos ligos, širdies nepakankamumas ir intoksikacija. Esant kardiogeniniam šokui ar širdies nepakankamumui, padidejęs kvėpavimo darbas atsiranda dèl plaučiuc edemos. Retas (bradipnejja) ar nereguliarus kvėpavimas paprastai yra grèsmingas ir vèlyvas klinikinis kvėpavimo nepakankamumo požymis. Svarbu žinoti, kad kvėpavimo dažnio sumažejjimas nuo greito iki "normalaus“ gali būti pasekmè blogejjančios būklès, kurią paprastai lydi blogejjanti sąmonè ir nuovargis.

Kitas svarbus klinikinis požymis - padidèjęs kvėpavimo darbas, esant kvėpavimo nepakankamumui. Padidejjusị kvèpavimo darbą rodo tarpšonkaulių ìsitraukimai, paradoksinis ar nesinchroninis kvėpavimo pobūdis, nosies sparnelių išsiplètimas (virpèjimas), pagalbinių raumenų dalyvavimas kvėpuojant, kūdikių ir mažų vaikų galvos paradoksiniai judesiai. Galvos paradoksiniai judesiai atsiranda, nes kaklo 
raumenys nèra pakankamai stiprūs, kad stabilizuotų kūdikio galvą, kai tuo metu laiptiniai kaklo ir galvos sukamieji raumenys dalyvauja kvėpuojant. Kiekvienas vaikas, patiriantis paradoksinius galvos judesius, kurie atsirado dèl ūminio kvépavimo nepakankamumo, turètų būti kruopščiai įvertintas ir atidžiai stebimas. Teisingas klinikinių požymių interpretavimas paprastai padeda kvėpavimo distreso požymius nesunkiai susieti su vyraujančia kvépavimo patologija. Inspiracinis stridoras rodo viršutinių kvėpavimo takų obstrukciją. Iškvėpimo stridoras vystosi, kai viršutinių kvejpavimo takų obstrukcija didejja, ir yra grèsmingas sunkios obstrukcijos ženklas, ypač jei kartu aktyviai dalyvauja pagalbiniai raumenys. Vyraujantis sunkus iškvėpimo stridoras kartu su čiuopiamu paradoksiniu pulsu yra sunkios viršutinių kvejpavimo takų obstrukcijos požymis, reikalingas neatideliotinos pagalbos [13].

Būtina atlikti plaučių auskultaciją, vertinti neinvazinès pulsoksimetrijos duomenis. Vaikams, kuriems yra ūminis kvėpavimo nepakankamumas, beveik visada nustatoma hipoksemija. Jei žmogaus akis pastebi cianozę, tai $\mathrm{O}_{2}$ ìsotinimas paprastai būna gerokai mažesnis nei 90 proc.

Galiausiai reikia įvertinti kvėpavimo nepakankamumo poveiki kitų organų sistemoms. Vaikų minutinis širdies tūris daugiausia priklauso nuo širdies susitraukimo dažnio. Bradikardija kartu su hipotenzija yra sunkios būklès požymis, rodantis kardiopulmoninès sistemos dekompensaciją. Sutrikusi sąmonė ar mažejantis sąmonès lygmuo yra hipoksemijos ir (ar) hiperkapnijos rezultatas - tai įspejjamieji kardiopulmoninès sistemos dekompensacijos ženklai.

Laboratoriniai ir rentgeniniai tyrimai yra svarbios diagnostinès priemonès, nustatant ir vertinant ūmini kvėpavimo nepakankamumą. Kraujo dujų analizė turètų būti laikoma tik viena dalele visos dèlionès, ji negali būti vienintelis veiksnys, nuo kurio priklausytų pagalbos apimtis. Kadangi liga progresuoja greitai, minutinè ventiliacija praktiškai gali išsilaikyti normali iki išsekimo momento, o hipoksemija ir hiperkapnija sparčiai progresuoti ir nulemti visišką kardiopulmoninès sistemos dekompensaciją (4 pav.).

Didžiausias vaikų ir suaugusiųjų kvėpavimo bei kardiopulmoninio nepakankamumo skirtumas yra ne fiziologija, bet ligos progresavimo greitis. Sprendžiant dèl dirbtinio kvėpavimo poreikio, svarbiausi kriterijai yra klinikiniai požymiai, bendroji paciento būklè. Pagrindiniai simptomai: vaikas neramus, tachipnèja, tachikardija, paradoksiniai galvos judesiai, nuovargis, nosies sparneliu išsiplètimas. Intubacija visada bus pavėluota, jei ji atliekama, kai yra bradipnèja, kvėpavimas negilus, sutrikusi sąmonè ir bradikardija.

\section{GYDYMAS}

Gydymas priklauso ne tik nuo konkrečios priežasties, bet ir nuo kvẻpavimo nepakankamumo sunkumo. Svarbu laiku suteikti pagalbą, nes kvépavimo nepakankamumas - pagrindinè vaikų kvẻpavimo ir širdies sustojimo priežastis.

Kadangi vaikus tenka gaivinti rečiau nei suaugusiuosius, gydytojai rezidentai, šeimos gydytojai turi mažesnes galimybes mokytis ir mažiau patirties atpažinti bei gydyti vaikų ūmini kvėpavimo nepakankamumą. Todèl labai svarbu suprasti anatominius ir fiziologinius ypatumus, mokèti atlikti paprastus veiksmus (pvz.: smakro pakèlimas, padèties suteikimas) juos pritaikyti, esant reikalui, naudoti neinvazines kvẻpavimo takų praeinamumą užtikrinančias priemones, tinkamai atlikti efektyvią ventiliaciją pro kaukę.

Deguonies turètų būti skiriama visiems vaikams, kuriems yra kvėpavimo nepakankamumas, kad $\mathrm{SpO}_{2}$ būtų palaikomas didesnis nei 92-94 proc. Inhaliuojamųjų vaistų, pavyzdžiui, adrenalino ar salbutamolio, inhaliacijos gali būti naudingos, norint užkirsti kelią tolesniam būklès

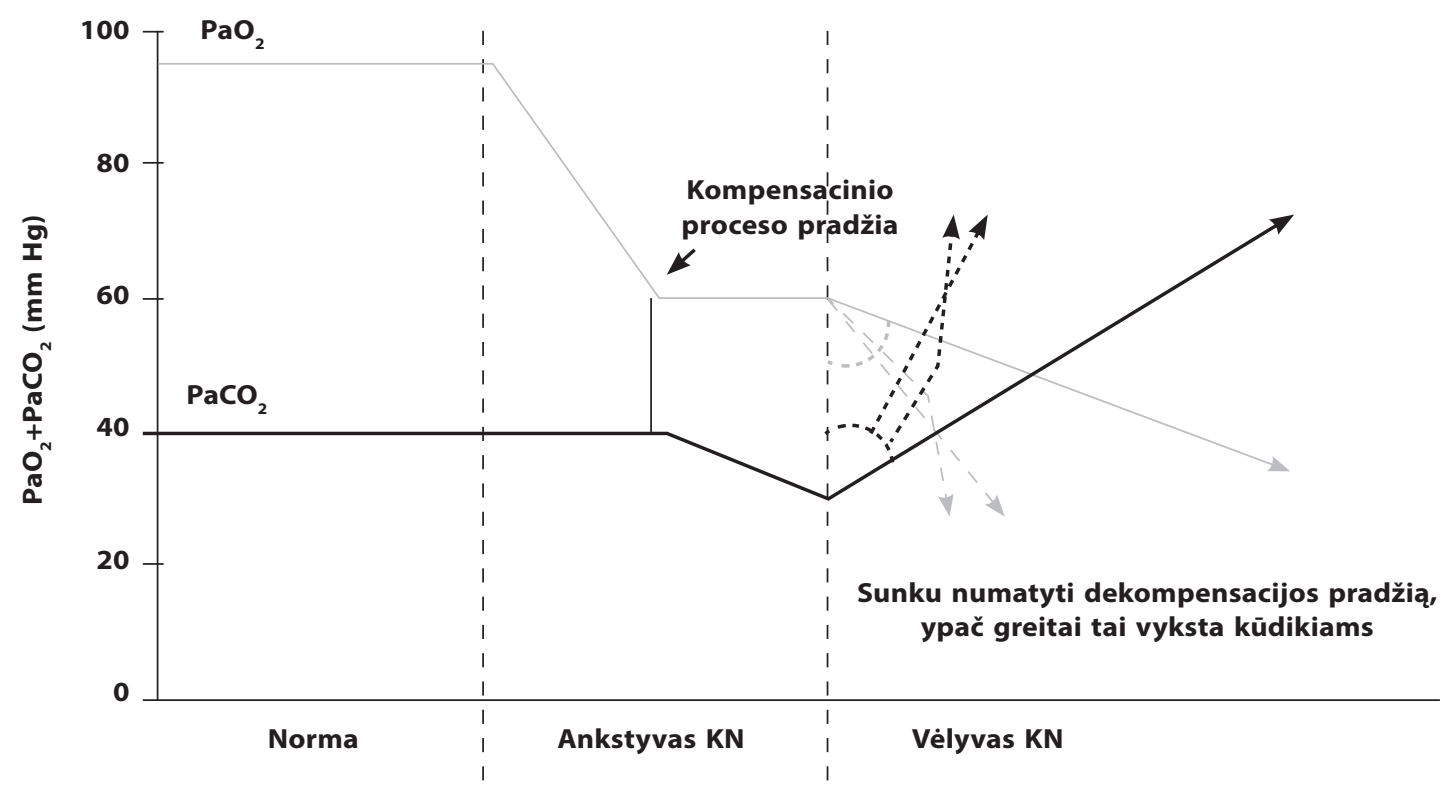

4 pav. Kraujo dujų pokyčiai kvèpavimo nepakankamumo metu 
blogèjimui kvėpavimo takų obstrukcijos atveju. Gydymo pradžioje būtina vaiką palikti su tẻvais ar globejjais. Taip jam nesukeliama papildomo streso ir nedidinamas $\mathrm{O}_{2}$ suvartojimas. Reikia vengti skausmingų ar stresinių procedūrų (venos punkcija, kraujo tyrimai), pagalvoti, ar būtina skubiai atlikti krūtinès rentgenogramą. Atlaisvinami kvépavimo takai, pvz.: išsiurbiamas susikaupęs sekretas nosyje ar burnoje, pakeliamas apatinis žandikaulis. Skiriama 100 proc. $\mathrm{O}_{2}$, nesukeliant vaikui streso. Neskiriama gerti skysčių, vaistų - prireikus ventiliacija ir trachejos intubacija saugesnè, kai skrandis yra tuščias. Rekomenduojama neinvazine $\mathrm{SpO}_{2}$ stebèsena (pulsoksimetrija).

Būklei blogejjant, vaikas atskiriamas nuo tèvų ar globejuc. Pagalbos tikslas - efektyvi ventiliacija. Atlaisvinami kvėpavimo takai, pvz.: išsiurbiamas susikaupęs sekretas nosyje ar burnoje, pakeliamas apatinis žandikaulis, ir pradedama ventiliacija Ambu tipo maišu 100 proc. $\mathrm{O}_{2}$. Punktuojama vena ir įkišamas periferinis venos kateteris. Rekomenduojama $\mathrm{SpO}_{2}$, ŠSD ir AKS stebėsena.

\section{Vaiku gydymo deguonimi ypatumai}

Papildomo $\mathrm{O}_{2}$ tiekimo būdų yra daugybè, kiekvieno jų efektyvumas priklauso nuo aparato galimybiu tiekti $\mathrm{O}_{2}$ pakankamo stiprumo srove:

- Nosies kateteriu galima tiekti 1-3 1/min. tékmès $\mathrm{O}_{2}$ srovę. Nosies kaniulès yra iprastas ir gerai toleruojamas deguonies tiekimo metodas.

- $\mathrm{O}_{2}$ kaukè ar palapinè taip pat tinkami būdai.

- Nuolatiniu teigiamu kvépavimo taku slègiu (angl. Continuous postitive airway pressure, CPAP) vaikas kvėpuoja spontaniškai. Sukuriamas teigiamas slėgis neleidžia alveolėms subliūkšti iškvėpimo pabaigoje. Rekomenduojama skiriamo dujų mišinio srovè turètuc būti 2-3 kartus didesnè už paciento minutinị kvépuojamąji tūrị. Jei CPAP skiriama neilgai, galima naudoti veido kaukę, tačiau ji turi gerai priglusti prie veido. Ilgam naudojimui rekomenduojama endotrachejinè intubacija. Iprastai vaikai gerai toleruoja pradinę $5 \mathrm{~cm}$ $\mathrm{H}_{2} \mathrm{O}$ CPAP terapiją, kurią palaipsniui galima didinti. Skiriant $>10 \mathrm{~cm} \mathrm{H}_{2} \mathrm{O}$ CPAP, rekomenduojama stebèti minutinị širdies tūrị.

- Iprastiné dirbtiné (mechaninè) plaučiuc ventiliacija (angl. mechanical ventilation, MV). Pacientui užtikrinama nustatyto kvėpavimo dažnio, ịpūtimo tūrio ir srovès greičio ventiliacija, nepriklausanti nuo paciento spontaninio kvėpavimo pastangų.

- Didelio dažnio dirbtinė plaučių ventiliacijai (angl. High frequency oscillatory ventilation, HFOV) naudojami specialūs aparatai, palaikantys ypač dažną (iki 900 k./ min.) labai mažo tūrio kvėpavimą.

- Neinvazinè teigiamo slègio ventiliacija (angl. Non-invasive Positive Pressure Ventilation, NPPV arba NIV) atliekama be intubacijos, t. y. be papildomo endotra- chejjinio ar tracheostominio ortakio. Neinvazinę ventiliaciją galima taikyti kur kas lanksčiau, nei tai ̨̧manoma pacientą intubavus. NIV suteikia daugiau lankstumo pradedant ir baigiant taikyti MV pacientui - geresnis toleravimas, lengvesnis atjunkymas. Leidžia pacientui beveik normaliai valgyti, gerti, bendrauti. Išsaugo kvėpavimo taku savisaugos, kalbos ir rijimo mechanizmus.

- Ekstrakorporinè membraninè oksigenacija (angl. Extracorporeal membrane oxygenation, ECMO) tinkama esant sunkiai kvejpavimo nepakankamumo formai. Ji naudojama tik tada, kai kiti metodai neefektyvūs. Moksliniai įrodymai, pagrindžiantys ECMO panaudojimą, yra gana prieštaringi.

\section{ACUTE RESPIRATORY FAILURE IN CHILDREN}

\section{JURGITA PEČIULYTÉ, VAIDOTAS GURSKIS \\ DEPARTMENT OF CHILDREN DISEASES LITHUANIAN UNIVERSITY OF HEALTH SCIENCES}

Keywords: respiratory failure, respiratory failure pathophysiology, respiratory anatomy of children, child respiratory failure treatment.

Summary. Acute respiratory failure is the most common medical emergency in children. Physiologic peculiarities explain the increased vulnerability of infants and children to any pathology affecting the respiratory tract. The importance of patient's history and correct physical examination for early recognition of an impending catastrophic progression of respiratory failure. Under most circumstances, correct physical examination alone allows one to pinpoint the cause to a particular part of the respiratory system and to make the appropriate decisions for a proactive and life-saving management of the critically ill child.

\section{LITERATŪRA}

1. Violeta Žilienè, Anatolijus Juozas Kondrotas, Egidijus Kèvelaitis., Ūminio kvèpavimo nepakankamumo etiologija ir patogenezè, MEDICINA (2004) 40 tomas.

2. Rogers M.C., Nichols D.G, Textbook of Pediatric Intensive Care, 3rd edition, 1996, Williams\&Wilkins, 97, 731-52.

3. 2. Fleisher G.R., Ludwig S. Textbook of Pediatric Emergency Medicine, 4th edition, 2000, Lippincott Williams\&Wilkins, p. 553-64.

4. Kristina Stravinskaitè-Biekšienè., Kvèpavimo funkcijos nepakankamumas: šiuolaikinis požiūris., Pulmonologija, imunologija IR alergologija 2011/Nr.2 (9).

5. Mathers CD, Boerma T, Ma Fat D. Global and regional causes of death. Br Med Bull 2009;92:7-32.

6. Pearson GA, Ward-Platt M, Harnden A, Kelly D. Why children die: avoidable factors associated with child deaths. Arch Dis Child 2011;96:927-31.

7. Cohen G, Katz-Salamon M. Development of chemoreceptor responses in infants. Respir Physiol Neurobiol 2005;149:233-42.

8. Deoras KS, Wolfson MR, Searls RL, Hilfer SR, Shaffer TH. Developmental changes in tracheal structure. Pediatr Res 1991;30:170-5.

9. Boyden EA. Notes on the development of the lung in infancy and early childhood. Am J Anat 1967;121:749-61.

10. Jurg Hammer. Acute respiratory failure in children. Paediatric Respiratory Reviews 14 (2013) 64-69.

11. Hammer J, Reber A, Trachsel D, Frei FJ. Effect of jaw-thrust and continuous positive airway pressure on tidal breathing in deeply sedated infants. J Pediatr 2001;138:826-30.

12. Reber A, Bobbia SA, Hammer J, Frei FJ. Effect of airway opening manoeuvres on thoraco-abdominal asynchrony in anaesthetized children. Eur Respir J 2001; 17:1239-43.

13. Argent $A C$, Newth $C J$, Klein $M$. The mechanics of breathing in children with acute severe croup. Intensive Care Med 2008;34:324-32. 